\title{
Monitoring Least Weasels after a Winter Peak of Lemmings in Taimyr: Body Condition, Diet and Habitat Use
}

\author{
NICOLE FEIGE, ${ }^{1}$ DOROTHEE EHRICH,${ }^{2}$ IGOR Y. POPOV ${ }^{3}$ and SIM BROEKHUIZEN ${ }^{4}$
}

(Received 29 March 2011; accepted in revised form 10 January 2012)

\begin{abstract}
Least weasels are highly specialized small-rodent predators. Despite the fact that they are hypothesized to play an important role in generating the lemming cycles, a key process for the functioning of the terrestrial tundra ecosystem, very little is known about the biology of these miniature carnivores in the Arctic. At Mys Vostochny in western Taimyr, Russia, least weasels were observed for the first time during a lemming peak in 2005, but not in two subsequent years with low lemming densities. Here we report observations about weasel signs in lemming winter nests, body condition, habitat use, and diet in summer 2008, a year when lemmings had been numerous under the snow but populations crashed before the summer, and least weasels were abundant. Stable isotope analyses revealed that weasel diet was dominated by Siberian lemmings during spring. As expected, given lower resource availability when the lemming population crashed, weight (taking into account body length) was somewhat lower in 2008 than in 2005. Tracking tunnels and trapping showed that in summer least weasels mostly used sheltered habitats such as rocky outcrops and driftwood. Together with surveys of lemming winter nests, tracking tunnels appeared to be a promising method for monitoring least weasels in the Arctic tundra.
\end{abstract}

Key words: least weasel, Mustela nivalis, predator, tundra, lemming cycles, Lemmus sibiricus, lemming winter nests, tracking tunnels, monitoring, stable isotope analysis, Taimyr

RÉSUMÉ. La belette pygmée est un prédateur de petits rongeurs hautement spécialisé. Malgré les hypothèses lui attribuant un rôle important pour la génération des cycles de lemmings, un processus clé pour le fonctionnement de l'écosystème terrestre de la toundra, la biologie de ce carnivore miniature est très peu connue dans l'Arctique. À Mys Vostochny, dans l'ouest du Taimyr (Russie), des belettes pygmées ont été observées pour la première fois pendant une année d'abondance de lemmings en 2005, mais pas au cours des deux années suivantes caractérisées par de faibles densités de lemmings. Nous reportons ici des observations sur les signes de belettes dans les nids d'hiver de lemmings ainsi que sur la condition corporelle, les préférences d'habitat et le régime alimentaire de belettes à l'été 2008, une année où les lemmings étaient nombreux sous la neige, mais où leur effectif a chuté avant l'été, et où les belettes pygmées étaient de nouveau nombreuses. Des analyses d'isotopes stables ont montré que le régime alimentaire des belettes était dominé par le lemming sibérien au printemps. Comme attendu, étant donné la diminution de la quantité de ressources disponibles en présence de la chute de population de lemmings, la masse (corrigée par la taille) était un peu inférieure en 2008 par rapport à celle reportée en 2005. Les résultats de pièges à empreintes et de captures ont montré que les belettes pygmées utilisaient surtout des habitats protégés comme des rochers ou des amoncellements de bois échoué. Les pièges à empreintes semblent constituer une méthode prometteuse pour le suivi de populations de belettes pygmées dans la toundra arctique, qui peut être complémentaire à l'inspection de nids d'hiver de lemmings.

Mots clés : belette pygmée, Mustela nivalis, prédateur, toundra, cycles de lemmings, Lemmus sibiricus, nids d'hiver, pièges à empreintes, suivi de population, analyse d'isotopes stables, Taimyr

Révisé pour la revue Arctic par Nicole Giguère.

\footnotetext{
${ }^{1}$ Department of Animal Ecology, Netherlands Institute of Ecology (NIOO-KNAW), PO Box 50, NL-6700 AB Wageningen, The Netherlands; present address: NABU-Naturschutzstation e. V., Im Hammereisen 27e, 47559 Kranenburg, Germany; feige.nicole@gmail.com

${ }^{2}$ Institute of Arctic and Marine Biology, University of Tromsø, N-9037 Tromsø, Norway

${ }^{3}$ A.N. Severtsov Institute of Ecology and Evolution RAS, 33 Leninskij Prospekt, Moscow, 119071, Russia

${ }^{4}$ Alterra, Centre for Ecosystem Studies, PO Box 47, NL-6700 AA Wageningen, The Netherlands

(C) The Arctic Institute of North America
} 
Ласка является высокоспециализированным хищником, питающимся мелкими грызунами. Несмотря на существование гипотезы о том, что она играет существенную роль в возникновении циклических колебаний численности леммингов, ключевого процесса в функционировании наземных экосистем тундры, о биологии этого самого мелкого хищника в Арктике известно крайне мало. Впервые мы наблюдали ласку на мысе Восточный (западное побережье п-ова Таймыр, Россия) в 2005 году при пике численности леммингов. В последующие два года, когда плотность леммингов была низкой, ласка не встречалась. В статье приведены данные о следах посещения лаской зимних гнёзд леммингов, морфометрических характеристиках, использовании местообитаний и питании ласки летом 2008 года, когда численность леммингов была высокой в подснежный период, но резко упала в момент схода снежного покрова. Анализ стабильных изотопов показал, что весной в питании ласки преобладали сибирские лемминги. Как и ожидалось, при уменьшении доступности ресурсов в результате падения численности леммингов, отношение веса к длине тела у пойманных ласок было несколько ниже, чем в 2005 году. Следовые туннели и отловы ловушками показали, что ласки придерживаются местообитаний с хорошими укрытиями, такими как нагромождения камней или принесенные водой деревья. Совместно с осмотром подснежных гнезд леммингов следовые туннели являются перспективным методом наблюдения за ласками в арктической тундре.

Ключевые слова: ласка, Mustela nivalis, тундра, хищник, циклические колебания численности леммингов, Lemmus sibiricus, следовые туннели, подснежные гнезда леммингов, анализ стабильных изотопов, Таймыр, мониторинг

\section{INTRODUCTION}

Weasels (Mustela nivalis) are the smallest mammalian carnivores in the Arctic. They are specialist predators of small rodents, which they hunt year-round, following them into their tunnels in the subnivean space in winter (King and Powell, 2007). It has been suggested that weasels, together with stoats ( $M$. erminea), play a key role in shaping the conspicuous population cycles of boreal and Arctic small rodents (Hanski et al., 2001; Gilg et al., 2003; Ekerholm et al., 2004). However, very little is known about the biology of these small mustelids in the Arctic. This is particularly true for least weasels (M. nivalis nivalis), which are difficult to investigate and rarely monitored.

Broekhuizen et al. (2007) report that least weasels appeared in the area of the Pyasina Delta in western Taimyr $\left(74^{\circ} 07^{\prime} \mathrm{N}, 86^{\circ} 43^{\prime} \mathrm{E}\right.$; Fig. 1) during a lemming peak in 2005 and were suddenly abundant, despite not having been observed in the area during eight previous expeditions to this site between 1990 and 2004 (Broekhuizen et al., 2006). Least weasels had notably not been observed in the area during rather intensive fieldwork in the lemming peak summers of 1991 and 1994 (Rykhlikova and Popov, 1995; Popov, 2009). It is not known whether least weasels colonized this area in winter 2004-05, or whether they had been present in the region before, but at such low densities that they had not been observed (Broekhuizen et al., 2007). In the two years following the lemming peak of 2005, lemming numbers were low, and not a single least weasel was observed in the area. In 2006, a few lemming nests with signs of weasel predation were found, but in 2007 no signs of weasel activity were recorded during three weeks of fieldwork (Broekhuizen et al., 2007). Assuming a period of three years for the lemming cycle in Taimyr (Kokorev and Kuksov, 2002), a lemming peak was expected in 2008. Our first questions were thus whether least weasels would again be abundant at Mys Vostochny in 2008, indicating that the population described in 2005 was a resident population whose abundance was tracking the lemming cycle, and whether weasels would be equally numerous in the study area as during the previous lemming peak.

As far as we know, this is the northernmost studied population of least weasels in Eurasia, although their distribution has been reported to extend up to $76^{\circ} \mathrm{N}$ on Taimyr (IUCN, 2011). Given the presence of least weasels in summer 2008, we aimed at investigating several aspects of their biology in the Pyasina Delta. First, body condition was assessed and compared to the data from 2005. Second, we investigated the diet of the least weasels. Least weasels are indeed highly specialized small-rodent predators, which prey mainly on lemmings in the Arctic (King and Powell, 2007). In summer, however, the eggs and chicks of the numerous birds breeding in the tundra represent an alternative resource for tundra predators. If lemmings get scarce, least weasels may shift to alternative prey, but little is known about the extent to which they do so. In 2005, most least weasels were observed in the rocky outcrops of the tundra, in driftwood along the shore, and close to the cabins of the camp. Our third aim here was to characterize the habitat use of least weasels more specifically, addressing in particular the extent to which they occur in open tundra compared to more sheltered places. Finally we discuss the usefulness of lemming winter nest surveys and tracking tunnels for monitoring the presence and abundance of least weasels in the Arctic tundra.

\section{METHODS}

\section{Study Area}

The study was carried out at Mys Vostochny on the northern shore of the Pyasina Delta in northwestern Taimyr (Fig. 1). According to Walker et al. (2005), the study area is situated in bioclimatic subzone B, and the vegetation is classified as rush/grass, forb, cryptogam tundra. The landscape is characterized by gently rolling hills reaching $53 \mathrm{~m}$ asl (Vysokaya Hill, Fig. 1) and wet river valleys. In 


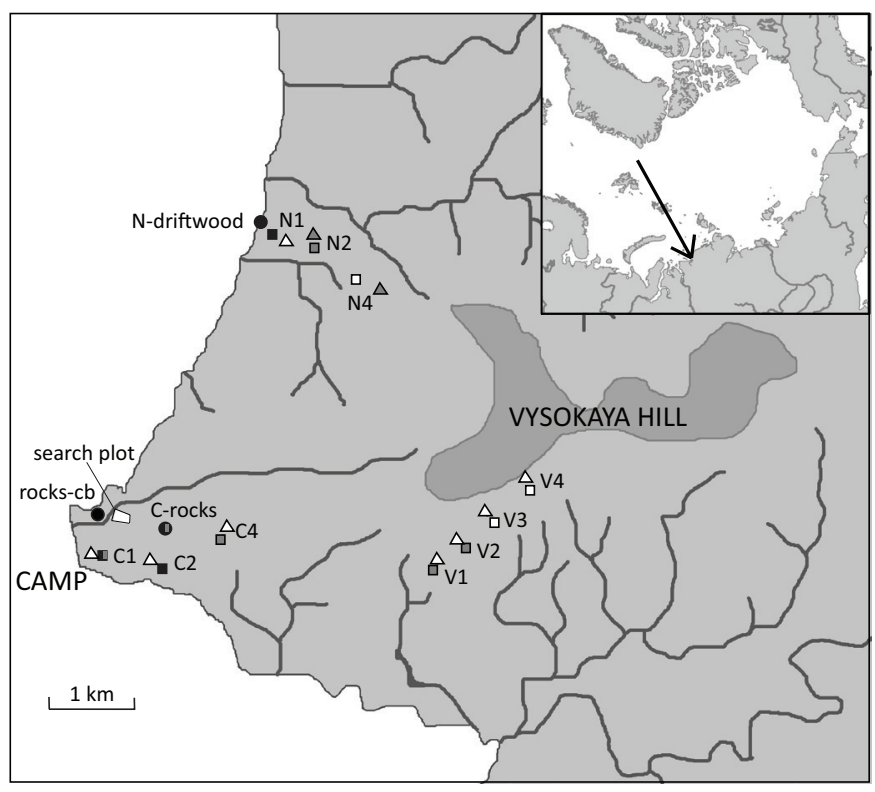

FIG. 1. Map of the study area at Mys Vostochny. The insert shows the location of the study area in northwestern Taimyr, Russia. Tracking tunnel locations are indicated by squares for pairs of tunnels in willow-sedge tundra, triangles for pairs of tunnels in hummock tundra, and circles for pairs of tunnels in rocks or driftwood. Filled black symbols indicate tunnels where least weasel tracks were recorded, and grey symbols indicate lemming tracks.

the valleys, the tundra is humid and dominated by grasses, sedges, and mosses, whereas on the watersheds it is drier, interspersed with open patches, and dominated by prostrate shrubs, forbs, lichen and mosses (Pakina, 2006; Chuprova and Chuprov, 2006). Rocky outcrops occur on some watersheds.

\section{Signs of Weasel Activity: Lemming Winter Nest Survey}

To assess the presence of least weasels in the study area in winter 2007-08, we surveyed lemming winter nests on the permanent search plot established in 2005 (Fig. 1; Broekhuizen et al., 2007). This plot was about 1.5 ha in size and situated in a shallow, sloping grass-sedge-willow marshy tundra valley. As we were mainly interested in signs of weasel presence, we did not attempt to attribute the winter nests to lemming species. However, because the search plot was situated in good winter habitat for Siberian lemmings (Lemmus sibiricus) (Dunaeva, 1948), and because this species dominates the study area, we assumed that most observed winter nests belonged to Siberian lemmings, rather than to collared lemmings (Dicrostonyx torquatus), the second but less frequent lemming species in the study area (Popov, 2009). Winter nests had been removed from the plot in the previous years, and nests found in summer 2008 could thus be attributed with certitude to winter 2007-08. Each nest was measured and inspected for signs of weasel occupation or predation, such as lemming fur, lemming remains, or weasel scats. As the search plot was rather small, we also recorded and examined winter nests found incidentally outside the survey plot and winter nests on two line transects (16.5 km and $21 \mathrm{~km}$ long). Walking along the transect, the observer recorded all nests situated up to $3 \mathrm{~m}$ on each side of the centre line (6 m wide strip) and some nests situated up to $10 \mathrm{~m}$ to each side $(20 \mathrm{~m}$ wide strip). Although we were careful to record only nests that looked fresh, we cannot exclude the possibility that a few nests from the previous winter may have been counted in this part of the survey (Sittler, 1995).

\section{Weasel Trapping and Body Measurements}

Weasels were live-trapped between 6 and 17 July 2008, using seesaw traps (Whitlock weasel traps, Thévenin, 1952; King, 1973). Traps were placed in the same locations as in 2005: around the camp, along the shoreline close to the camp, and on a rocky outcrop in the tundra (C-rocks), all within an area of about $1 \mathrm{~km}^{2}$ (Fig. 1). In addition, traps were placed on the search plot. Traps were baited with fish and maintained open for up to eight hours per day, while checked every three hours or at shorter intervals. We marked captured weasels individually with fur color before releasing them to avoid measuring the same individuals again in case of retrapping. To facilitate handling, weasels were anaesthetized with ether. If possible, we recorded fur color, body weight, body length (without tail), as well as sex and tail, ear, and hind foot lengths. Sex was assigned by measuring the anogenital distance, which is two to three times as long in females as in males.

Since lemmings were also snap-trapped in the study area (Popov, 2009), four least weasels were incidentally killed in these traps and were measured in the same way as the live-trapped individuals. In addition, they were dissected, and their reproductive status was assessed. To assess body condition of weasels trapped in 2008 compared to those trapped in 2005 (Broekhuizen et al., 2007), we used a linear model to estimate the effect of year on weasel weight, taking into account body length. Using the residuals of a regression of weight against measures of body size is a common way to assess body condition (Schulte-Hostedde et al., 2005), although its usefulness is controversial (e.g., Green, 2001). The linear model approach we chose here is very similar to the residuals approach. A difference in food availability between the years may affect the average weight given body length (additive effect of year and body length), or the slope of the increase of weight with body length (interaction of year with body length), or both. Therefore, two different models were considered and compared with Akaike's Information Criterion corrected for small sample sizes (AICc) (Burnham and Anderson, 2004).

\section{Tracking Tunnels: Habitat Use}

Tracking tunnels have been successfully used to monitor the abundance and distribution of weasels in Scotland (Graham, 2002) and small mammals such as rats and mice in New Zealand (Brown et al., 1996). For this study, tunnels were made of sections of plastic pipes $(50 \mathrm{~cm}$ long and $11 \mathrm{~cm}$ wide) as described in Graham (2002; Fig. 2). Each 

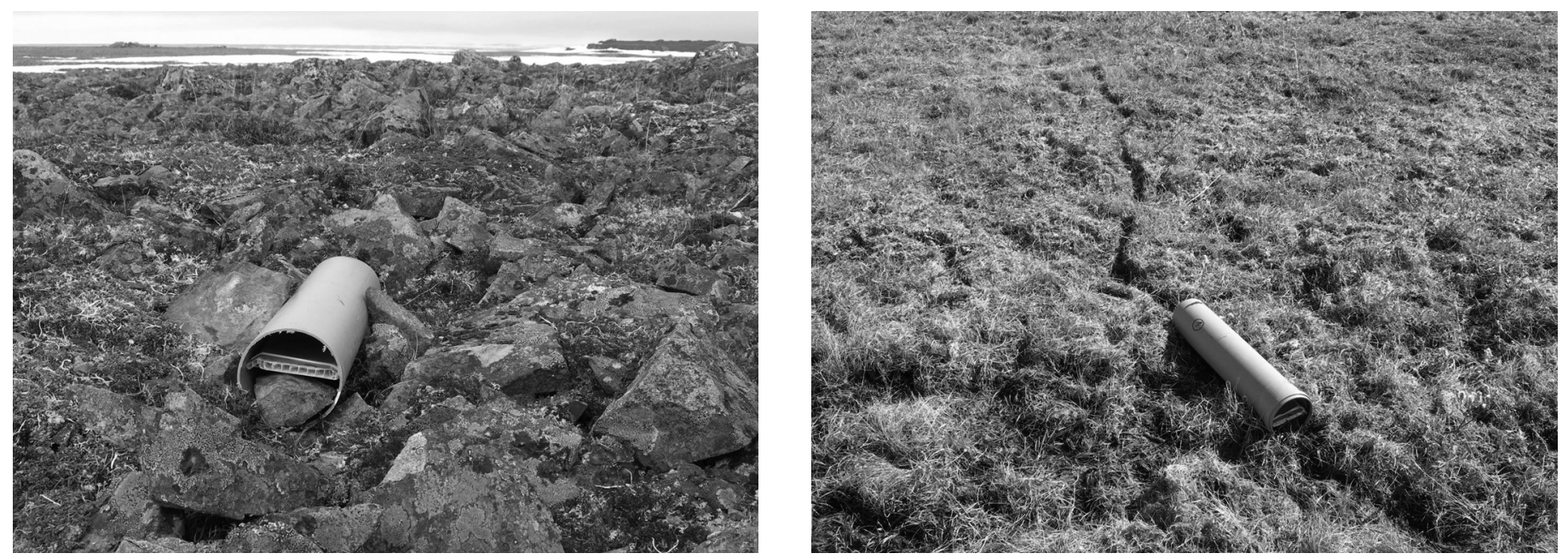

FIG. 2. Tracking tunnels as used at Mys Vostochny. Left: A tunnel among rocks. Right: A tunnel placed on a lemming runway in the tundra.

tunnel contained a plastic tracking board with an inkpad in the middle consisting of a piece of absorbent cleaning cloth. A transparent chemical ink containing $17 \%$ ferric nitrate and $25 \%$ polyethylene glycol was used. On each side of the ink pad, a tracking paper was attached to the board with rubber bands. Tracking papers were of brown wrapping paper that had been previously sprayed with a solution of $5 \%$ tannic acid in $47.5 \%$ ethanol and $47.5 \%$ water.

Here we tested whether tracking tunnels could be used to monitor least weasels in Arctic tundra by recording activity and presence in different habitats. We placed 20 tunnels in each of two different tundra types: humid willow-sedge tundra and drier hummock tundra. In both habitats, we placed the tunnels in lemming runways whenever possible and filled the space below the tracking board with moss to make it more natural for animals to pass through the tunnels. Pairs of tunnels were placed at intervals of 15 to $20 \mathrm{~m}$. We chose patches of the two habitats that were close to each other and placed three or four groups of four tunnels in three areas (units C, N, and V) about $2.5 \mathrm{~km}$ apart (Fig. 1). In addition, we placed six tunnels in rocky outcrops (near unit C) and four tunnels in driftwood (near unit N), two habitats where it is easy for least weasels to hide and where they had been observed in 2005 (Broekhuizen et al., 2007). Two of the rocky outcrop tunnels (in plot rocks-cb; Fig. 1) were made of cardboard instead of plastic pipe. The tunnels were set out between 30 June and 2 July and checked at least every five days until 22 July, which for most of them resulted in four tracking periods of five days each.

\section{Stable Isotope Analysis: Diet Inference}

Stable isotope analysis (SIA) is a useful tool for diet reconstruction and food web studies (e.g., Kelly, 2000, for a review). The ratio of ${ }^{13} \mathrm{C}$ to ${ }^{12} \mathrm{C}$ (expressed as $\delta^{13} \mathrm{C}$ relative to a standard) and of ${ }^{15} \mathrm{~N}$ to ${ }^{14} \mathrm{~N}$ (expressed as $\delta^{15} \mathrm{~N}$ ) reflects the ratios of these isotopes in the main dietary items an organism has consumed over a certain time (e.g., Inger and Bearhop, 2008). Here we analyzed muscle samples from weasels killed in snap traps (one sample from the back leg was taken from each of four individuals and from an additional weasel that died in a live trap) and fur samples from live-trapped individuals (one sample of dorsal fur from each of two individuals; Table 1). Considering the small body size and high metabolic rate of weasels, muscle is likely to reflect diet during approximately the last month (Dalerum and Angerbjorn, 2005). Fur samples reflect the diets during the period when the fur was growing. All captured weasels had brown dorsal fur, indicating that they had been molting in June, or that they were born under the snow in spring (Broekhuizen et al., 2007). In addition, samples of main prey were analyzed: muscle of Siberian and collared lemmings; egg content of passerines, waders, and geese; muscle samples of birds accidentally killed in snap traps or of dead chicks; and samples of fish (see Appendix 1 for species list and sample numbers). Preparation of muscle and egg samples was carried out as described by Ehrich et al. (2010). Fur samples were washed in 2:1 chloroform-methanol to remove hair surface fat, dried, clipped to very small pieces with scissors, and weighed as for the muscle samples. Isotope ratios were determined by combustion in a mass spectrometer at the Stable Isotopes in Nature Laboratory (SINLAB, Canadian Rivers Institute, Biology Department, University of New Brunswick, Fredericton, New Brunswick). Because the presence of lipids in samples can introduce a bias in $\delta^{13} \mathrm{C}$, lipids were extracted chemically from some egg samples, and the rest of the samples were corrected for lipid content arithmetically, using the equations from Ehrich et al. (2010).

The proportions of different prey in the diet of weasels were estimated with a Bayesian mixing model as implemented in the R-package SIAR (Parnell et al., 2010). For this analysis, prey were grouped into the following categories based on their isotopic and taxonomic similarity: Siberian lemmings, collared lemmings, bird egg content and muscle (except rock ptarmigan, Lagopus mutus), rock ptarmigan eggs, and fish. The stable isotope values of a consumer are equal to the mean values of its diet minus a discrimination 
TABLE 1. Least weasels captured in July 2008 at Mys Vostochny (western Taimyr). Trap indicates whether the weasel was caught in a live trap or a snap trap. Age is given as juvenile, subadult, or adult. SIA shows whether samples were taken for stable isotope analysis ( $\mathrm{M}$ - muscle; F - fur).

\begin{tabular}{|c|c|c|c|c|c|c|c|c|c|c|c|c|}
\hline \multirow[b]{2}{*}{ Ind } & \multirow[b]{2}{*}{ Date } & \multirow[b]{2}{*}{ Trap } & \multirow[b]{2}{*}{ Habitat } & \multirow[b]{2}{*}{ Recaptures } & \multirow[b]{2}{*}{ Sex } & \multirow[b]{2}{*}{ Age } & \multirow[b]{2}{*}{ Weight (g) } & \multicolumn{4}{|c|}{ Length (mm) } & \multirow[b]{2}{*}{ SIA } \\
\hline & & & & & & & & body & tail & ear & foot & \\
\hline 1 & 2.07 & snap & tundra & - & $\mathrm{m}$ & adult & 66.9 & 184 & 18.6 & 13.4 & 23.6 & M \\
\hline 2 & 5.07 & snap & tundra & - & $\mathrm{f}$ & subadult & 49.1 & 152 & 10.7 & 11.5 & 20.6 & M \\
\hline 3 & 6.07 & live & rocks & - & $\mathrm{f}$ & subadult & 41.2 & 167 & 15.4 & 12.2 & 20.1 & M \\
\hline 4 & 6.07 & live & rocks & 1 & $\mathrm{f}$ & juvenile & 50 & 151 & 12.8 & 11.8 & 20.1 & - \\
\hline 5 & 6.07 & live & camp & - & $\mathrm{m}$ & adult & 77.2 & 185 & 19.1 & 16.8 & 15.2 & - \\
\hline 6 & 7.07 & snap & tundra & - & $\mathrm{m}$ & adult & 86.2 & 190 & 16 & 14 & 26.7 & $\mathrm{M}$ \\
\hline 7 & 7.07 & live & camp & 1 & $\mathrm{~m}$ & adult & 86 & 180 & 22 & 13.5 & 23.9 & $\mathrm{~F}$ \\
\hline 8 & 11.07 & live & camp & 3 & $\mathrm{f}$ & adult & 80 & 180 & 20.1 & 13.8 & 16.4 & $\mathrm{~F}$ \\
\hline 9 & 17.7 & snap & tundra & - & $\mathrm{m}$ & adult & 74.9 & 180 & 12.5 & 10.8 & 23.2 & M \\
\hline 10 & 21.07 & live & camp & - & $?$ & juvenile & 70 & 148 & 13 & 13 & 20.8 & - \\
\hline
\end{tabular}

factor, which reflects the fact that certain biochemical processes discriminate against the heavy isotope (Deniro and Epstein, 1981). Discrimination factors are likely to be tissue- and species-specific, and the results of mixing models have been shown to be sensitive to changes in discrimination factors (Bond and Diamond, 2011). As discrimination has not been estimated for least weasel muscle and fur, we used average values determined for these tissues in smaller northern carnivores (mink Mustela vison, BenDavid et al., 1997; red fox Vulpes vulpes, Roth and Hobson, 2000; and arctic fox Vulpes lagopus, Lecomte et al., 2011): 1.1 and 3.0 for muscle and 2.4 and 3.4 for fur, for $\delta^{13} \mathrm{C}$ and $\delta^{15} \mathrm{~N}$, respectively. The estimation of the mixing proportions in SIAR is based on Markov Chain Monte Carlo resampling (Parnell et al., 2010). We used 4000000 MCMC iterations, of which the first 500000 were discarded as burn-in, and assessed convergence as suggested by the authors of SIAR.

\section{RESULTS}

Despite clear indications that lemming numbers had been high during winter 2007-08 (many winter nests in suitable habitats, extensive traces of grazing, and large amounts of lemming feces in snow beds), lemming densities were rather low in summer 2008 (Popov, 2009). Least weasels were nevertheless present in the study area in summer 2008, and they were regularly observed around the camp and on rocky outcrops in the tundra.

\section{Lemming Winter Nest Survey}

On the 1.5 ha search plot, we found 132 winter nests of lemmings. Broekhuizen et al. (2007) had observed signs of weasel predation only in winter nests with a diameter of more than $14 \mathrm{~cm}$. In 2008, 122 nests on the search plot had a diameter of $14 \mathrm{~cm}$ or more, and 10 had a diameter of less than $14 \mathrm{~cm}$. In total, 14 nests showed signs of predation by weasels $(11 \%$; 13 nests $>14 \mathrm{~cm}$, one nest $<14 \mathrm{~cm}): 13$ nests were lined with fur, and one nest contained a lemming skull. The signs of predation were less pronounced than in 2005 , however, and nests were only very sparsely lined with fur. Three weasel latrines were found close to three of these 14 lemming nests.

In addition, 332 winter nests were found outside the search plot: 48 on the $16.5 \mathrm{~km}$ transect between the camp and unit N, 149 on the $21 \mathrm{~km}$ transect close to unit V (Fig. 1); and 135 incidentally. From these nests, 37 (also $11 \%$ ) contained signs of weasel predation, i.e., fur or remains of lemmings. The percentage was the same considering only nests with a diameter greater than $14 \mathrm{~cm}$ (35 of $307=11 \%$ ).

\section{Live Trapping and Body Measurements}

In total, we trapped ten weasels: four females, five males, and one individual for which the sex could not be determined (Table 1). Six weasels were caught in live traps: two individuals in the rocky outcrop (C-rocks on Fig. 1), and four individuals in and around the camp. Among the latter, one female was recaptured three times. No weasels were captured on the search plot, although traps were maintained open for up to eight hours per day. Four individuals were caught incidentally in snap traps, three in tundra near the rocky outcrops (less than $10 \mathrm{~m}$ from the rocks) and the fourth near a pile of driftwood on the shore. All observed and trapped weasels had a brown dorsal coat, indicating that they had been moulting in June, or that they were born under the snow in spring (Broekhuizen et al., 2007).

Mean weight of weasels in 2008 was $55 \mathrm{~g}(\mathrm{SD}=17 \mathrm{~g})$ for females and $78 \mathrm{~g}(\mathrm{SD}=8 \mathrm{~g}$ ) for males (Table 1). In 2008, in contrast to 2005 , no males with a body weight over $90 \mathrm{~g}$ were observed. Mean body length (without tail) in 2008 was $163 \mathrm{~mm}(\mathrm{SD}=14 \mathrm{~mm})$ for females and $184 \mathrm{~mm}(\mathrm{SD}$ $=4 \mathrm{~mm}$ ) for males (Table 1). The results of the linear models indicated better body condition in least weasels in 2005 than in 2008. According to AICc, both models were equally adequate (difference in $\mathrm{AICc}=0.54$ ). The additive model revealed that weight was on average $9.6 \mathrm{~g}$ lower in 2008 than in 2005 ( $\mathrm{SE}=4.47, p=0.046)$, representing a decrease of $13 \%$ in the overall average weight. Weight increased by $1.23 \mathrm{~g}$ for each $1 \mathrm{~mm}$ of body length ( $\mathrm{SE}=0.16, p<0.001$ ). According to the results of the interaction model, weight increased by $1.19 \mathrm{~g}(\mathrm{SE}=0.17)$ in 2008 compared to $1.25 \mathrm{~g}$ 

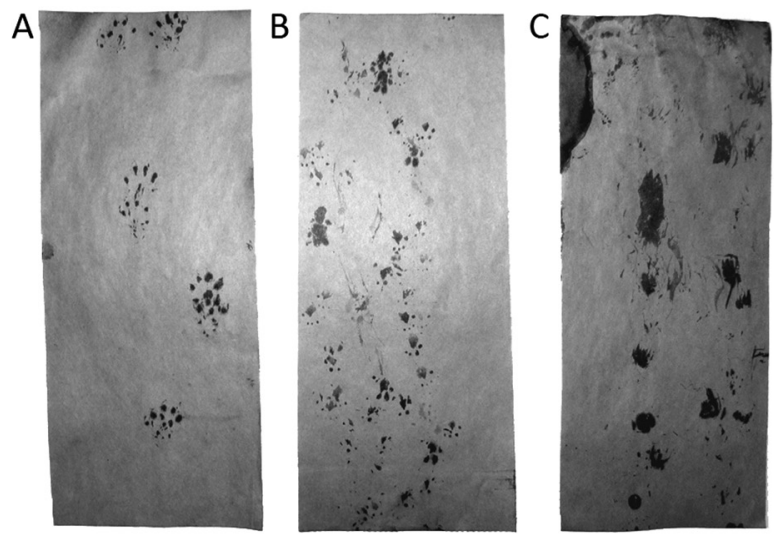

FIG. 3. Examples of tracks obtained in the tracking tunnels. A) Least weasel, B) Siberian lemming, C) Collared lemming.

per mm body length $(\mathrm{SE}=0.16)$ in 2005 , and the difference between the two slopes was significant $(p=0.035)$.

\section{Tracking Tunnels and Habitat Use}

Tracking tunnels revealed the presence of both lemmings and weasels. Tracks of least weasel could easily be distinguished from tracks of lemmings (Fig. 3). Most tracks were obtained in the tunnels placed in rocky outcrops and in the driftwood along the shore (Table 2). In these sheltered places, weasel activity was recorded during the whole study period. In the rocky outcrop on unit $\mathrm{C}$, activity may have been reduced somewhat by live trapping, which was carried out in the same place during part of the period. Some of the tunnels placed in open tundra were also used by weasels, but only in willow-sedge tundra, where all Siberian lemming tracks were also recorded (Table 2). These tunnels were the closest to the camp $(\mathrm{C} 1$; Fig. 1$)$ or to the shore $(\mathrm{C} 2$ and N1). No weasel tracks were recorded in tunnels in the tundra, where there was no sheltered habitat nearby (unit $\mathrm{V})$, despite the fact that lemmings were present. Weasel activity was registered in tundra tunnels only during the first two tracking periods.

\section{Stable Isotopes}

After correcting for discrimination, the stable isotope values obtained for muscle $(\mathrm{n}=5)$ and fur $(\mathrm{n}=2)$ of weasels were similar, and there was little variation among individuals. The values were very close to the signatures of Siberian lemmings, suggesting that lemmings constituted the main part of the weasel diet (Fig. 4A). This suggestion was confirmed by the results of the mixing model analysis (Fig. 4B). Siberian lemmings were estimated to represent about $40 \%$ of the diet of weasels (mode of the posterior distribution), whereas collared lemmings were estimated to represent $30 \%$. Ptarmigan, other birds, and fish were estimated to be less important, with posterior probability intervals not excluding 0 .

\section{DISCUSSION}

Least weasels were present and rather numerous at Mys Vostochny in 2008, as we had predicted assuming that lemming populations vary in a three-year cycle (Kokorev and Kuksov, 2002) and that least weasel abundance follows lemming abundance. Our observations thus strongly indicate that this High Arctic weasel population at Mys Vostochny survived two years of low lemming densities after the lemming peak year 2005 and managed to establish itself in the area. The numerous observations of weasels in summer 2008 make it seem unlikely that weasels had been present before 2004 without being noticed during nine previous expeditions, not even during two lemming peak years. Thus, evidence available up to now is consistent with the interpretation that weasels colonized the area of Mys Vostochny at the end of 2004, although we cannot firmly rule out their presence in the area also long before.

As weasel live-trapping was not carried out according to a systematic schedule in both lemming peak years, the trapping data could not be used to compare the abundance of weasels in 2008 and 2005. Our general impression was, however, that weasels were encountered about equally often in both years. The survey of lemming winter nests revealed considerably fewer weasel signs in 2008 than in 2005. In $2005,52 \%$ of the lemming nests with a diameter of more than $14 \mathrm{~cm}$ (56 nests) showed signs of predation on the search plot, and remains of lemmings were found in many nests (Broekhuizen et al., 2007). In 2008, only $11 \%$ of the winter nests (13 nests) inspected on the search plot showed signs of predation, and $11 \%$ of the nests surveyed in a larger area also showed these signs. Thus both the proportion of winter nests with signs of weasel activity and the density of such nests on the search plot were lower in 2008 than in 2005 . However, the very high predation rate recorded on the search plot in 2005 may not necessarily reflect a high overall predation rate in that year. As the plot was relatively small, Broekhuizen et al. (2007) estimate that all the lemmings predated on this plot in winter 2004-05 could have been killed by only one weasel; thus, the high predation rate does not necessarily indicate particularly high weasel densities. Therefore it is also difficult to use the winter nest data from the search plot to compare relative weasel abundance between the two high lemming density winters. Our rate of $11 \%$ of winter nests with signs of weasel predation, as observed also over the larger area, lies within the range of values observed for stoat predation on Nearctic collared lemming (D. groenlandicus) nests in eastern Greenland, where between $0 \%$ and $14 \%$ of the nests had been occupied by stoats, and the stoat dynamics followed lemming dynamics with a lag of one year (Sittler, 1995; Gilg et al., 2006). On Bylot Island in 2007, a year with high lemming densities, $6 \%$ of winter nests showed signs of stoat predation (Duchesne, 2009). 
TABLE 2. Number of tunnels with tracks of least weasels (W), Siberian lemmings (L), or collared lemmings (D) in each tunnel pair and trapping period. WS refers to tunnels in willow-sedge tundra and Hum refers to tunnels in hummock tundra. Dates are the means of the five-day tracking periods.

\begin{tabular}{|c|c|c|c|c|}
\hline \multirow[b]{2}{*}{ Plot } & \multicolumn{4}{|c|}{ Period (mean dates) } \\
\hline & $1-6$ July 2008 & $6-11$ July 2008 & $11-16$ July 2008 & $16-21$ July 2008 \\
\hline V1-WS & $2 \mathrm{~L}$ & $2 \mathrm{~L}$ & $2 \mathrm{~L}$ & $2 \mathrm{~L}$ \\
\hline \multicolumn{5}{|l|}{ V1-Hum } \\
\hline V2-WS & & $1 \mathrm{~L}$ & $1 \mathrm{~L}$ & \\
\hline \multicolumn{5}{|l|}{ V2-Hum } \\
\hline \multicolumn{5}{|l|}{ V3-WS } \\
\hline \multicolumn{5}{|l|}{ V3-Hum } \\
\hline \multicolumn{5}{|l|}{ V4-WS } \\
\hline \multicolumn{5}{|l|}{ V4-Hum } \\
\hline C1-WS & $1 \mathrm{~W}$ & $2 \mathrm{~W}$ & & \\
\hline \multicolumn{5}{|l|}{ C1-Hum } \\
\hline C2-WS & $1 \mathrm{~W}$ & & & \\
\hline C2-Hum & & & & $1 \mathrm{~L}$ \\
\hline C4-WS & & $1 \mathrm{~L}$ & $1 \mathrm{~L}$ & \\
\hline \multicolumn{5}{|l|}{ C4-Hum } \\
\hline N1-WS & & $1 \mathrm{~L}+1 \mathrm{~W}$ & & \\
\hline \multicolumn{5}{|l|}{ N1-Hum } \\
\hline N2-WS & $1 \mathrm{~L}$ & $1 \mathrm{~L}$ & $1 \mathrm{~L}$ & $2 \mathrm{~L}$ \\
\hline N2-Hum & & & & 1D \\
\hline \multicolumn{5}{|l|}{ N4-WS } \\
\hline N4-Hum & & & & $1 \mathrm{~L}$ \\
\hline C-rocks ${ }^{1}$ & $3 \mathrm{~W}, 1 \mathrm{~L}$ & & $3 \mathrm{~W}$ & \\
\hline Rocks-cb & & & $1 \mathrm{~W}$ & $3 \mathrm{~W}$ \\
\hline $\mathrm{N}$-driftwood ${ }^{1}$ & $2 \mathrm{~W}$ & $1 \mathrm{~W}$ & $2 \mathrm{~W}$ & $1 \mathrm{~W}$ \\
\hline
\end{tabular}

${ }^{1}$ The C-rocks and Driftwood plots each had four tunnels.

\section{Body Condition and Diet}

The weight relative to body length of weasels captured in 2008 was on average lower than that of weasels captured in 2005. Although body length is not a perfect measure of structural size and weight is not directly related to the amount of metabolizable tissue carried by an animal, Schulte-Hostedde et al. (2005) conclude that the residuals of a regression of weight against body size are often useful as index of body condition. We therefore assume that our result indicates poorer body condition of least weasels in 2008 than in 2005. The lower weight of weasels in 2008 may be related to lower lemming densities. Despite numerous indications that lemmings had been abundant under the snow (many winter nests, extensive traces of grazing, and large amounts of lemming feces), lemming densities were rather low after snow melt, and the lemming specialists such as snowy owls (Bubo scandiaca), rough-legged buzzard (Buteo lagopus) and pomarine skua (Stercorarius pomarinus - one unsuccessful nest) were not breeding in summer 2008 (Popov, 2009). We can thus assume that after a winter with plenty of food, the resources available to least weasels were scarcer than in the lemming peak summer of 2005 (Broekhuizen et al., 2007). This lower weight may also indicate that alternative prey, such as eggs and chicks of birds, did not fully compensate for the decrease in resources caused by the lemming population crash.

Assuming that the general discrimination factors used were correct, the stable isotope analyses clearly showed that lemmings - in the first place Siberian lemmings - constituted the main part of the diet of the analyzed weasels. This finding confirms that least weasels are clearly small rodent specialists (King and Powell, 2007). Furthermore this result indicates that the least weasels were still concentrating on their preferred prey, the lemmings, despite the ongoing population crash during the snow melting period (Popov, 2009). The high proportion of collared lemmings in the diet was somewhat surprising given the low abundance of this species in the study area in 2008 (Table 2; Popov, 2009). This stable isotope result may be explained in several ways. It is possible that the discrimination factor we used was too large for nitrogen, and that therefore the weasel values were underestimated on the nitrogen scale and moved closer to collared lemmings than they truly were. Alternatively, the relatively high proportion of collared lemmings may be attributed to the fact that there were more collared lemmings in the study area earlier in the season. There are no data available on lemming distribution on Taimyr during winter, but the habitat of the two lemming genera is indeed more similar in this season (Rodgers and Negus, 1986). Muscle samples reflect the diet about one month prior to sampling (Dalerum and Angerbjorn, 2005), and the fur of the captured weasels is likely to have grown in spring.

\section{Habitat Use}

Weasels were observed mostly around the cabins of the camp or on the rocky outcrops in the tundra. Tracks were also recorded mostly in tunnels located on rocky outcrops 

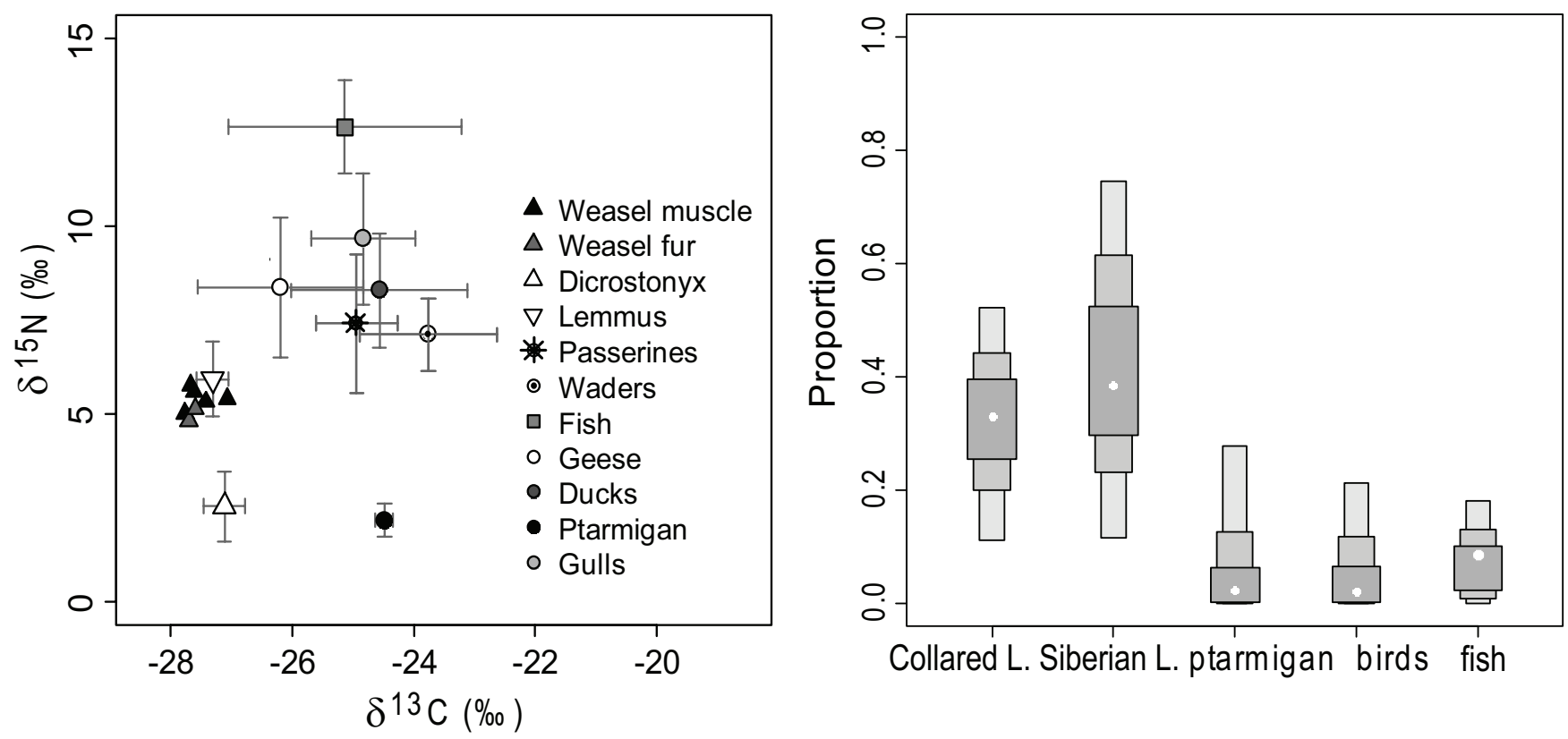

FIG. 4. Left: Stable isotope values for muscle and fur of least weasels plotted in comparison with mean values for different groups of potential prey. Error bars indicate standard deviations. Right: Proportions of five prey groups in the diet of least weasels, as estimated from the stable isotope data in a mixing model. L. refers to lemmings. For each prey group, the white dot shows the mode of the posterior distribution, and the grey boxes the $50 \%, 75 \%$, and $95 \%$ posterior credibility intervals.

and in driftwood along the shore, and all four weasels caught in snap traps were caught very close to either rocks or driftwood. Therefore, it seems that weasels were concentrated around such sheltered habitats and probably made excursions into the tundra to hunt lemmings. This conclusion is supported by two facts: first, in the tundra, tracks were recorded only in tunnels situated relatively close to sheltered places. The weasels did not seem to move far into the open tundra despite the fact that lemming traces were also recorded there (Fig. 1). Second, tracks in the tundra tunnels were recorded only in the first two tracking periods. This fact may suggest that weasels moved less to the open tundra later in the season. As lemming densities were decreasing over the summer, they may have become so low later in the season that foraging in the tundra was not effective any more. At the same time, snow bunting (Plectrophenax nivalis) chicks had hatched, and weasels may have increasingly predated snow bunting nests in this period. This suggestion is underlined by the fact that of 22 snow bunting nests included in a nest success survey carried out during the same period, 14 were indeed predated between 11 and 20 July (Laurent Demongin, pers. comm. 2008). As snow buntings hide their nests well in rocks or among driftwood, they are usually inaccessible to predators other than weasels. The weasels may have switched to preying on snow buntings in an attempt to compensate for the population crash of their preferred prey. However, this hypothesized use of passerine birds as alternative prey was not reflected in the stable isotope data, because it occurred after the time window reflected by the tissues we collected.

\section{Weasel Monitoring}

Our results showed that tracking tunnels seem to be a promising method for monitoring weasels in a noninvasive way and with rather little effort. Tracking tunnels during the snow-free period could be used as a complementary approach to monitoring of lemming winter nest predation, in order to get some information about weasel activity in summer and in winter. This result contrasted with the results from three sites in southern Arctic shrub tundra, where very few tracks were recorded in the tunnels, despite the fact that stoats and weasels were observed and caught in snap traps, and winter nests predated by small mustelids were found (Arctic Predators project, www.arctic-predators.uit.no, unpubl. data). The tunnels may have provided better results at Mys Vostochny because preferred habitats of weasels could be identified and targeted specifically. In addition, it is possible that densities of weasels were higher there than in any of the more southern sites.

Our results confirmed that least weasels were highly specialized predators largely depending on lemmings. In the future, it would be very interesting to investigate their dynamics with respect to lemming dynamics in order to assess their potential contribution to generating the lemming cycles. Tracking tunnels in summer combined with winter nest surveys over a larger area in permanently marked plots are methods that could be used in the High Arctic. 
APPENDIX 1. Mean stable isotope values for C and N (with standard deviations) for samples collected at Mys Vostochny in 2007 and 2008 are given for each species. Tissues analyzed are indicated as $\mathrm{M}$ - muscle, E - egg, and Fu - fur.

\begin{tabular}{|c|c|c|c|c|}
\hline Species & $\mathrm{n}$ & $\delta^{13} \mathrm{C}(\mathrm{SD})$ & $\delta^{15} \mathrm{~N}(\mathrm{SD})$ & Tissue \\
\hline Mustela nivalis & 7 & $-26.08(0.61)$ & $8.36(0.25)$ & $\mathrm{M}, \mathrm{Fu}$ \\
\hline Lemmus sibiricus & 21 & $-27.31(0.27)$ & $5.93(0.99)$ & M \\
\hline Dicrostonyx torquatus & 4 & $-27.12(0.33)$ & $2.55(0.93)$ & $\mathrm{M}$ \\
\hline Anser albifrons & 5 & $-26.01(0.64)$ & $6.99(0.26)$ & $\mathrm{E}$ \\
\hline Branta bernicla & 16 & $-25.96(1.16)$ & $10.78(4.31)$ & E, M \\
\hline Branta ruficollis & 1 & -26.18 & 7.51 & $\mathrm{E}$ \\
\hline Clangula hyemalis & 1 & -23.54 & 9.36 & $\mathrm{M}$ \\
\hline Somateria spectabilis & 1 & -25.59 & 7.21 & $\mathrm{E}$ \\
\hline Arenaria interpres & 1 & -25.51 & 8.73 & E \\
\hline Calidris alpina & 3 & $-23.50(0.62)$ & $6.52(0.42)$ & $\mathrm{E}$ \\
\hline Calidris ferruginea & 1 & -22.53 & 6.34 & E \\
\hline Calidris minuta & 7 & $-24.04(1.30)$ & $7.76(1.15)$ & E, M \\
\hline Charadrius hiaticula & 1 & -23.97 & 8.24 & $\mathrm{E}$ \\
\hline Phalaropus fulicarius & 1 & -24.73 & 7.24 & E \\
\hline Pluvialis fulva & 6 & $-23.22(0.66)$ & $6.69(0.62)$ & $\mathrm{E}, \mathrm{M}$ \\
\hline Pluvialis squatarola & 5 & $-23.81(1.52)$ & $6.65(0.54)$ & E \\
\hline Larus heuglini & 10 & $-25.12(0.59)$ & $9.16(1.25)$ & $\mathrm{E}$ \\
\hline Larus hyperboreus & 2 & $-23.44(0.53)$ & $12.18(2.09)$ & E \\
\hline Lagopus mutus & 3 & $-24.48(0.14)$ & $2.17(0.45)$ & $\mathrm{E}$ \\
\hline Anthus cervinus & 1 & -25.13 & 8.74 & $\mathrm{M}$ \\
\hline Calcarius lapponicus & 4 & $-24.920 .45)$ & $7.53(0.61)$ & M \\
\hline Eremophila alpestris & 6 & $-24.96(0.90)$ & $7.19(3.33)$ & M \\
\hline Luscinia svecica & 1 & -24.69 & 8.28 & M \\
\hline Oenanthe oenanthe & 1 & -24.24 & 7.89 & $\mathrm{M}$ \\
\hline Plectrophenax nivalis & 8 & $-25.03(0.73)$ & $7.17(1.03)$ & $\mathrm{M}, \mathrm{E}$ \\
\hline Coregonus autumnalis & 2 & $-24.46(0.86)$ & $13.11(0.14)$ & M \\
\hline Coregonus lavaretus & 3 & $-25.37(1.27)$ & $11.99(1.07)$ & M \\
\hline Coregonus muksun & 3 & $-26.95(0.22)$ & $13.36(0.47)$ & M \\
\hline Coregonus nasus & 2 & $-22.37(2.49)$ & $11.02(0.47)$ & M \\
\hline Lota lota & 1 & -25.85 & 14.64 & M \\
\hline
\end{tabular}

\section{ACKNOWLEDGEMENTS}

The 2008 expedition was the last one organized by Dr. Barwolt S. Ebbinge (Alterra, Wageningen-UR) and Dr. Bart A. Nolet (Netherlands Institute of Ecology). This means that, unfortunately, no further data about the weasel from the tundra near Mys Vostochny are to be expected in the near future. We would like to thank all participants in the expedition for their contributions, especially R. Bom for helping with the transects, A. Datema for helping with the tracking tunnels and transects, and P. de Vries, who assisted with weasel catching and data collection on the weasel plot. We thank J. Stien for help in the lab. We also thank three anonymous reviewers for their useful comments on a previous version of the manuscript. This study was supported by the Netherlands Organization for Scientific Research (NWO grant 047.017.038), the Russian Foundation for Basic Research, and the Norwegian Research Council through the IPY project "Arctic Predators." This is publication 5199 of the Netherlands Institute of Ecology.

\section{REFERENCES}

Ben-David, M., Hanley, T.A., Klein, D.R., and Schell, D.M. 1997. Seasonal changes in diets of coastal and riverine mink: The role of spawning Pacific salmon. Canadian Journal of Zoology 75(5):803-811.

Bond, A.L., and Diamond, A.W. 2011. Recent Bayesian stable-isotope mixing models are highly sensitive to variation in discrimination factors. Ecological Applications 21(4):1017-1023.

Broekhuizen, S., Mulder, J.L., and Popov, I.Y. 2006. The occurrence of the least weasel Mustela nivalis nivalis near Mys Vostochny. In: Ebbinge, B.S., and Mazurov, Y.L., eds. Pristine wilderness of the Taimyr Peninsula: 2005 report. Moscow: Heritage Institute. 117-132.

Broekhuizen, S., Mulder, J.L., Müskens, G.J.D.M., and Popov, I.Y. 2007. The least weasel (Mustela nivalis nivalis) in northwestern Taimyr, Siberia, during a lemming cycle. Lutra 50(2):67-90.

Brown, K.P., Moller, H., Innes, J., and Alterio, N. 1996. Calibration of tunnel tracking rates to estimate relative abundance of ship rats (Rattus rattus) and mice (Mus musculus) in a New Zealand forest. New Zealand Journal of Ecology 20(2):271 - 275.

Burnham, K.P., and Anderson, D.R. 2004. Multimodel inference: Understanding AIC and BIC in model selection. Sociological Methods \& Research 33:261-304.

Chuprova, I., and Chuprov, V. 2006. The vegetation of the Pyasina section of the Great Arctic State Strict Nature Reserve. In: Ebbinge, B.S., and Mazurov, Y.L., eds. Pristine wilderness of the Taimyr Peninsula: 2005 report. Moscow: Heritage Institute. 57-78.

Dalerum, F., and Angerbjörn, A. 2005. Resolving temporal variation in vertebrate diets using naturally occurring stable isotopes. Oecologia 144(4):647-658.

Deniro, M.J., and Epstein, S. 1981. Influence of diet on the distribution of nitrogen isotopes in animals. Geochimica et Cosmochimica Acta 45(3):341 - 351. 
Duchesne, D. 2009. Habitat selection, reproduction and winter predation on lemmings in the Arctic. MSc thesis, Université Laval, Québec, Canada.

Dunaeva, T.N. 1948. Comparative review of the ecology of tundra voles on Yamal peninsula [in Russian]. In: Formozov, A.N., ed. Ecologia nazenykh pozvonochnykh pluostrova Yamal [Ecology of terrestrial vertebrates of Yamal Peninsula]. Trudy In-ta geograghii AN SSSR [Transactions of the Institute of Geography, Academy of Science of the USSR]. M.-L.: Izdatelstvo AN SSSR 41. 78-143.

Ehrich, D., Tarroux, A., Stien, J., Lecomte, N., Killengreen, S., Berteaux, D., and Yoccoz, N.G. 2010. Stable isotope analysis: Modelling lipid normalization for muscle and eggs from Arctic mammals and birds. Methods in Ecology and Evolution 2(1):66-76, doi:10.1111/j.2041-210X.2010.00047.x.

Ekerholm, P., Oksanen, L., Oksanen, T., and Schneider, M. 2004. The impact of short-term predator removal on vole dynamics in an arctic-alpine landscape. Oikos 106(3):457-468.

Gilg, O., Hanski, I., and Sittler, B. 2003. Cyclic dynamics in a simple vertebrate predator-prey community. Science 302(5646):866-868.

Gilg, O., Sittler, B., Sabard, B., Hurstel, A., Sané, R., Delattre, P., and Hanski, I. 2006. Functional and numerical responses of four lemming predators in High Arctic Greenland. Oikos 113:193-216.

Graham, I.M. 2002. Estimating weasel Mustela nivalis abundance from tunnel tracking indices at fluctuating field vole Microtus agrestis density. Wildlife Biology 8(4):279-287.

Green, A.J. 2001. Mass/length residuals: Measures of body condition or generators of spurious results? Ecology $82: 1473-1483$.

Hanski, I., Henttonen, H., Korpimäki, E., Oksanen, L., and Turchin, P. 2001. Small-rodent dynamics and predation. Ecology 82(6):1505-1520.

Inger, R., and Bearhop, S. 2008. Applications of stable isotope analyses to avian ecology. Ibis 150(3):447-461.

IUCN (International Union for Conservation of Nature). 2011. Mustela nivalis (least weasel). IUCN Red List of Threatened Species, Version 2011.2. www.iucnredlist.org.

Kelly, J.F. 2000. Stable isotopes of carbon and nitrogen in the study of avian and mammalian trophic ecology. Canadian Journal of Zoology 78:1 - 27.

King, C.M. 1973. A system for trapping and handling live weasels in the field. Journal of Zoology London 171:458-464.

King, C.M., and Powell, R.A. 2007. The natural history of weasels and stoats: Ecology, behaviour and management, 2nd ed. New York: Oxford University Press.
Kokorev, Y.I., and Kuksov, V.A. 2002. Population dynamics of lemmings, Lemmus sibiricus and Dicrostonyx torquatus, and arctic fox, Alopex lagopus on the Taimyr Peninsula, Siberia, 1960-2001. Ornis Svecica 12:139- 143.

Lecomte, N., Ahlstrøm, Ø., Ehrich, D., Fuglei, E., Ims, R.A., and Yoccoz, N.G. 2011. Intrapopulation variability shaping isotope discrimination and turnover: Experimental evidence in arctic foxes. PLoS ONE 6: e21357, doi:10.1371/journal.pone.0021357.

Pakina, A. 2006. Landscape: Brief characterisation of geological structure, relief and soils. In: Ebbinge, B.S., and Mazurov, Y.L., eds. Pristine wilderness of the Taimyr Peninsula: 2005 report. Moscow: Heritage Institute. 53-56.

Parnell, A.C., Inger, R., Bearhop, S., and Jackson, A.L. 2010. Source partitioning using stable isotopes: Coping with too much variation. PLoS ONE 5(3): e9672, doi:10.1371/journal. pone.0009672.

Popov, I.Y. 2009. Some characteristics of lemmings inhabitance in western Taimyr. Problems of animals study and protection in the North [In Russian]. In: Taskaev, A., ed. Proceedings of AllRussian Scientific Conference with International Participation, 16-20 November, Syktyvar, Komi Republic: Ural Division of the Russian Academy of Sciences. 194-196.

Rodgers A.R., and Lewis M.C. 1986. Diet selection in arctic lemmings (Lemmus sibiricus and Dicrostonyx groenlandicus): Demography, home range, and habitat use. Canadian Journal of Zoology 64:2717-2727.

Roth, J.D., and Hobson, K.A. 2000. Stable carbon and nitrogen isotopic fractionation between diet and tissue of captive red fox: Implications for dietary reconstruction. Canadian Journal of Zoology 78:848-852.

Rykhlikova, M.E., and Popov, I.Y. 1995. Lemmings in the northwestern Taimyr Arctic tundra: Population density, distribution of territories and relationships with other animals. Corax 16, Sonderheft 1:169-179.

Schulte-Hostedde, A.I., Zinner, B., Millar, J.S., and Hickling, G.J. 2005. Restitution of mass-size residuals: Validating body condition indices. Ecology 86(1):155-163.

Sittler, B. 1995. Response of stoats (Mustela erminea) to a fluctuating lemming (Dicrostonyx groenlandicus) population in North East Greenland: Preliminary-results from a long-term study. Annales Zoologici Fennici 32:79-92.

Thévenin, R. 1952. Les petits carnivores d'Europe. Paris: Payot. Walker, D.A., Raynolds, M.K., Daniels, F.J.A., Einarsson, E., Elvebakk, A., Gould, W.A., Katenin, A.E., et al. 2005. The circumpolar Arctic vegetation map. Journal of Vegetation Science 16(3):267-282. 